\title{
Concentration-dependent systemic response after inhalation of nano-sized zinc oxide particles in human volunteers
}

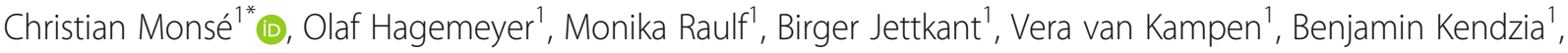 \\ Vitali Gering ${ }^{1}$, Günther Kappert ${ }^{2}$, Tobias Weiss ${ }^{1}$, Nadin Ulrich¹, Eike-Maximilian Marek', Jürgen Bünger', \\ Thomas Brüning ${ }^{1}$ and Rolf Merget ${ }^{1}$
}

\begin{abstract}
Background: Inhalation of high concentrations of zinc oxide particles $(\mathrm{ZnO})$ may cause metal fume fever. In an earlier human inhalation study, no effects were observed after exposure to $\mathrm{ZnO}$ concentrations of $0.5 \mathrm{mg} /$ $\mathrm{m}^{3}$. Further data from experimental studies with pure $\mathrm{ZnO}$ in the concentration range between 0.5 and 2 . $5 \mathrm{mg} / \mathrm{m}^{3}$ are not available. It was the aim of this experimental study to establish the concentration-response relationship of pure nano-sized $\mathrm{ZnO}$ particles.

Methods: Sixteen healthy subjects were exposed to filtered air and $\mathrm{ZnO}$ particles $\left(0.5,1.0\right.$ and $\left.2.0 \mathrm{mg} / \mathrm{m}^{3}\right)$ for $4 \mathrm{~h}$ on 4 different days, including $2 \mathrm{~h}$ of cycling with a low workload. The effects were assessed before, immediately after, and about $24 \mathrm{~h}$ after each exposure. Effect parameters were symptoms, body temperature, inflammatory markers and clotting factors in blood, and lung function.

Results: Concentration-dependent increases in symptoms, body temperature, acute phase proteins and neutrophils in blood were detected after $\mathrm{ZnO}$ inhalation. Significant effects were detected with $\mathrm{ZnO}$ concentrations of $1.0 \mathrm{mg} / \mathrm{m}^{3}$ or higher, with the most sensitive parameters being inflammatory markers in blood.

Conclusion: A concentration-response relationship with nano-sized $\mathrm{ZnO}$ particles in a low concentration range was demonstrated. Systemic inflammatory effects of inhaled nano-sized ZnO particles were observed at concentrations well below the occpational exposure limit for $\mathrm{ZnO}$ in many countries. It is recommended to reassess the exposure limit for $\mathrm{ZnO}$ at workplaces.
\end{abstract}

Keywords: Zinc oxide, Nanoparticles, Concentration-response relationship, Systemic effects, Inhalation study

\section{Background}

Zinc oxide fumes produced by activities such as thermal cutting, welding and melting may induce zinc fever after inhalation. Besides fever, typical symptoms include throat irritation, cough, minor respiratory symptoms, metallic taste, as well as flu-like symptoms, such as a general feeling of illness, myalgia, arthralgia or headache [1]. Typically, the symptoms occur after a latency period of $4-12 \mathrm{~h}$, and resolve themselves within $48 \mathrm{~h}$. Tolerance, which may

\footnotetext{
* Correspondence: monse@ipa-dguv.de

${ }^{1}$ Institute for Prevention and Occupational Medicine of the German Social Accident Insurance, Institute of the Ruhr-Universität Bochum (IPA), Bürkle-de-la-Camp-Platz 1, 44789 Bochum, Germany

Full list of author information is available at the end of the article
}

develop after repeated exposures, has been shown to be reversible after several exposure-free days [1]. Generally, zinc fever is assumed to have no long-term sequels, but there is no valid epidemiologic information available.

In previous human experimental inhalation studies, nearly all volunteers developed zinc fever after exposure to $5 \mathrm{mg} / \mathrm{m}^{3} \mathrm{ZnO}$ for $2 \mathrm{~h}[2,3]$. Conversely, lower $\mathrm{ZnO}$ concentrations of $2.5 \mathrm{mg} / \mathrm{m}^{3}$ for $2 \mathrm{~h}$ only induced a slight but significant increase in body temperature [3].

Thus far, only one study has analyzed leukocytes in blood after $\mathrm{ZnO}$ exposure, with the authors reporting no increase in polymorphonuclear neutrophilic granulocytes ( $\mathrm{ZnO}$ concentration range 2.76 to $37 \mathrm{mg} / \mathrm{m}^{3} ; 15$ to $120 \mathrm{~min}$. Exposure duration) [4]. 
Exposure to $0.5 \mathrm{mg} / \mathrm{m}^{3}$ ultrafine and fine $\mathrm{ZnO}$ particles produced no effects (symptoms, body temperature, blood and sputum parameters) in 12 subjects after inhalation for $2 \mathrm{~h}$ at rest [5].

Earlier studies showed an increase of blood leukocytes about $20 \mathrm{~h}$ after exposure to welding fumes of galvanized steel [6, 7]. An asymptomatic increase in highsensitive C-reactive protein (hsCRP) in the blood of 12 subjects after inhalation of metal inert gas (MIG) welding fumes of zinc-coated steel for $6 \mathrm{~h}$ at a zinc concentration of $1.5 \mathrm{mg} / \mathrm{m}^{3}$ was reported [8]. In a further study by the same working group, an increase in blood CRP (measured with a high sensitive (hs) ELISA) was detected after exposure to different concentrations of MIG brazing fumes of zinc-coated materials for $6 \mathrm{~h}$. The authors defined a No Observed Effect Level (NOEL) for systemic inflammation for welding fume concentrations $\left(\mathrm{PM}_{10}\right)$ between 1.4 and $2.0 \mathrm{mg} / \mathrm{m}^{3}$ (containing 1.1 to $1.5 \mathrm{mg} / \mathrm{m}^{3} \mathrm{ZnO}$ ), but did not rule out that the effects may be different for other processes, even with the same zinc content [9]. Three different welding fumes containing $\mathrm{Zn}$, traces of aluminum with/without copper showed a maximal increase in interleukin-6 (IL-6) $10 \mathrm{~h}$ after exposure, but no qualitative differences were observed in inflammatory parameters like CRP and serum amyloid A (SAA), even $29 \mathrm{~h}$ after exposure [10].

In summary, experimental inhalation studies investigating zinc containing welding fumes report that zincrelated inflammatory effects occur below $2.0 \mathrm{mg} / \mathrm{m}^{3}$ $\mathrm{ZnO}$. However, one study with low concentrations of pure $\mathrm{ZnO}\left(0.5 \mathrm{mg} / \mathrm{m}^{3}\right)$ reported no effects [5]. Thus, a precise NOEL cannot be defined with the available data, and as a consequence we aimed in the present study to define the concentration-response relationship for pure $\mathrm{ZnO}$ in this lower concentration range.

\section{Methods}

\section{Generation and characterization of $\mathrm{ZnO}$ nanoparticles}

The principle of the particle synthesis was based on the pyrolysis of atomized aqueous zinc formate solutions with a hydrogen-oxygen flame [11]. The mobility diameter of the generated primary particles was about $10 \mathrm{~nm}$. Depending on the $\mathrm{ZnO}$ concentration the primary particles formed aggregates and agglomerates in a range from $48 \mathrm{~nm}\left(0.5 \mathrm{mg} / \mathrm{m}^{3} \mathrm{ZnO}\right)$ to $86 \mathrm{~nm}\left(2.0 \mathrm{mg} / \mathrm{m}^{3} \mathrm{ZnO}\right)$. The particle diameters are comparable to those observed in an emission study of galvanized materials with different welding techniques [12]. A ceiling fan was used to homogenize the freshly generated $\mathrm{ZnO}$ nanoparticle atmospheres in the exposure unit [13]. Briefly, constant target concentrations with $0.5,1.0$ and $2.0 \mathrm{mg} / \mathrm{m}^{3} \mathrm{ZnO}$ were planned. Sham exposures $\left(0 \mathrm{mg} / \mathrm{m}^{3} \mathrm{ZnO}\right)$ were also performed with the flame generator operated with purified water without zinc salt.
There were negligible differences between target and measured concentrations (Table 1). The particle size distributions were monomodal with relatively small geometric standard deviations of 1.66 to 1.69 .

The purity of the airborne $\mathrm{ZnO}$ was $99.71 \%$. Three precursor solutions were prepared by dissolving 11.0, 22.5 and $46.0 \mathrm{~g}$ zinc formate dihydrate $\left(\mathrm{Zn}\left(\mathrm{CH}_{2} \mathrm{O}\right)_{2}{ }^{*} 2 \mathrm{H}_{2} \mathrm{O}\right.$, purity 98\%, Alfa Aesar GmbH, Karlsruhe, Germany) in $3.0 \mathrm{~mL}$ acetic acid (HAc), which acted as a stabilizer (purity 99\%, Merck GmbH, Darmstadt, Germany), and brought to a total volume of $1000 \mathrm{~mL}$ with purified water to yield $\mathrm{Zn}$ concentrations of $0.057,0.118$ and $0.240 \mathrm{~mol} / \mathrm{L}$, respectively. The hydrogen volumetric flow rate was set to $10.0 \mathrm{~L} /$ min and the oxygen flow to $5.0 \mathrm{~L} / \mathrm{min}$. Argon flow rate was $4.0 \mathrm{~L} / \mathrm{min}$. The atomizing gas was nitrogen (nitrogen generator, model NGM 22, cmc instruments GmbH, Eschborn, Germany), and the atomizing pressure was set to 0.30 bar. Typical flow rates of the aqueous zinc formate solutions were in the range of $0.90-1.00 \mathrm{~mL} / \mathrm{min}$.

The air exchange rate was set at 12 per hour $\left(360 \mathrm{~m}^{3} /\right.$ h) with a room temperature of $23.5^{\circ} \mathrm{C}\left(+/-0.3^{\circ} \mathrm{C}\right)$ and a relative humidity of $47.0 \%(+/-1.7 \%)$.

A Scanning Mobility Particle Sizer (SMPS, model 3080, TSI Inc., Shoreview MN, USA, equipped with a long differential mobility analyzer and a butanol condensation particle counter, TSI model 3776) measured the particle size distributions in the exposure unit. The number concentration and size distributions were determined every 5 min. Mass concentration measurements of airborne $\mathrm{ZnO}$ were recorded at 1-min intervals using a tapered elemental oscillating microbalance (TEOM, model 1400a, Rupprecht and Patashnik, Albany NY, USA). Trace gas analyses of nitric oxides $\left(\mathrm{NO}, \mathrm{NO}_{2}\right)$ were performed via online chemical ionization mass spectroscopy at 1-s intervals (Airsense.net, MS4 GmbH, Rockenberg, Germany) to control the pyrolysis process. All measurement results of airborne $\mathrm{ZnO}$ concentrations, mobility particle diameter, geometric standard deviations as well as particle number concentration are listed in Table 1 (averaged over all exposure days for each exposure condition) (Fig. 1).

\section{Participants}

Sixteen healthy nonsmoking volunteers (8 women, 8 men) with a median age of 26 (range 19-42) years participated in the study (Table 2). The subjects had no previous exposure to airborne zinc compounds and did not show bronchial hyperresponsiveness to methacholine as assessed with a reservoir method [14]. Standard baseline laboratory parameters were within normal ranges. Seven subjects sensitized to ubiquitous aeroallergens (atopy screen sx1, Phadiatop, ImmunoCAP system, ThermoFisher Scientific, Phadia AB, Uppsala, Sweden) without any clinical manifestation were included, but exposures were performed outside of the allergy season. 
Table 1 Measured parameters of airborne ZnO nanoparticles

\begin{tabular}{lllll}
\hline $\begin{array}{l}\text { Target concentration } \\
{\left[\mathrm{mg} / \mathrm{m}^{3}\right]}\end{array}$ & $\begin{array}{l}\text { Measured concentration } \\
{\left[\mathrm{mg} / \mathrm{m}^{3}\right]}\end{array}$ & $\begin{array}{l}\text { Mobility particle diameter } \\
{[\mathrm{nm}]}\end{array}$ & $\begin{array}{l}\text { Geometric standard deviation } \\
{[\mathrm{GSD}]}\end{array}$ & $\begin{array}{l}\text { Particle number concentration } \\
{\left[\# / \mathrm{cm}^{3}\right]}\end{array}$ \\
\hline 0.0 & $0.016(+/-71.8 \%)$ & - & - & $<500$ \\
0.5 & $0.514(+/-2.4 \%)$ & $47.8(+/-2.4 \%)$ & 1.66 & $1.69 \mathrm{E}+06(+/-3.5 \%)$ \\
1.0 & $1.013(+/-1.1 \%)$ & $62.8(+/-2.7 \%)$ & 1.68 & $2.03 \mathrm{E}+06(+/-4.1 \%)$ \\
2.0 & $2.014(+/-1.2 \%)$ & $85.8(+/-4.0 \%)$ & 1.69 & $2.53 \mathrm{E}+06(+/-9.2 \%)$ \\
\hline
\end{tabular}

\section{Study design}

Exposures were performed in an exposure unit at our institute [15]. Subjects were exposed for $4 \mathrm{~h}$, with 2 weeks intervals for each subject. The subjects were generally at rest, except for short periods of moderate physical activity on a cycle ergometer set to $15 \mathrm{~L} / \mathrm{min} /$ $\mathrm{m}^{2}$ (corresponding to a work load of 60 watt (range 30-96 watt), which was separated into 4 blocks of $30 \mathrm{~min}$ each (total $120 \mathrm{~min}$ )). Exposures were randomized and double blinded, with the exception of the exposures to $2.0 \mathrm{mg} / \mathrm{m}^{3} \mathrm{ZnO}$, which were not blinded according to instructions by the ethics committee. Medical examinations were performed before, directly after, and approximately $24 \mathrm{~h}$ after the start of exposure. Additionally, examinations were performed before the first (baseline test) and after the last exposure (final test) (Fig. 2).

At each examination, subjects answered a questionnaire and underwent a physical examination, blood sampling, lung function testing, and measurements of fractional exhaled nitric monoxide (FeNO) and body temperature. In addition, vital functions (electrocardiogram, blood pressure) were monitored during the exposures.

\section{Questionnaire}

All subjects answered a questionnaire addressing flu-like symptoms (at least 1 of 3 symptoms: feeling of fever, feeling sick and muscle pain), and additionally all symptoms were graded according to severity (not at all (1 score point), barely ( 2 points), little ( 3 points), moderate ( 4 points), strong (5 points), very strong (6 points)). To avoid any information bias we added questions about itching nose, abdominal pain, metallic taste in mouth, dry nose, throat irritation, headache, cough, burning eyes, feeling warm, itching skin, nausea, shortness of breath, dry eyes, sweating, irritation of the eyes, general irritability, feeling cold, chills, runny nose, feeling unwell, bleeding eyes and muscle cramps.

\section{Body temperature}

Subjects measured their own body temperatures using an infrared method that recorded the temperature in both ears. This was performed at each examination, and at intervals of $2 \mathrm{~h}$ from the beginning of the exposure to $24 \mathrm{~h}$ afterwards, but not during sleep (Braun Thermoscan Pro 4000, WelchAllyn, Hechingen, Germany).

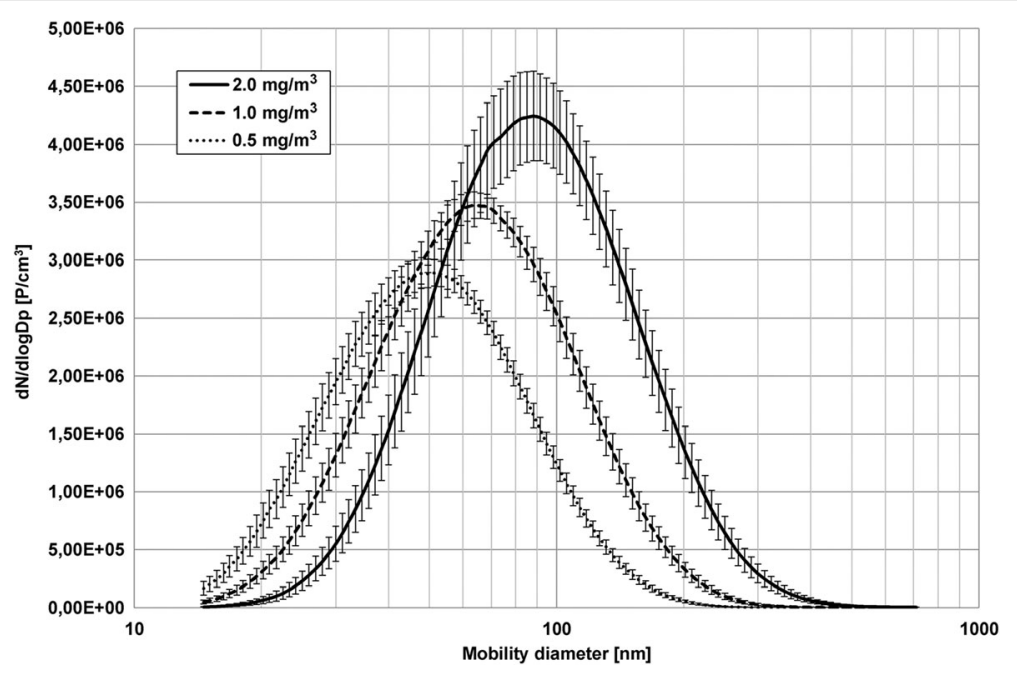

Fig. 1 Particle size distributions of airborne $\mathrm{ZnO}$ concentrations at $0.5,1.0$ and $2.0 \mathrm{mg} / \mathrm{m}^{3}$. In addition, the error bars of each individual size channel are shown 
Table 2 Characteristics of the study subjects

\begin{tabular}{llll}
\hline & $\begin{array}{l}\text { Total } \\
n=16\end{array}$ & $\begin{array}{l}\text { Male } \\
n=8\end{array}$ & $\begin{array}{l}\text { Female } \\
n=8\end{array}$ \\
\hline Age [years] & $26(19-42)$ & $28(19-42)$ & $24(23-32)$ \\
Height $[\mathrm{cm}]$ & $178(155-191)$ & $182(176-191)$ & $164(155-182)$ \\
Weight $[\mathrm{kg}]$ & $72(51-104)$ & $83(61-104)$ & $59(51-91)$ \\
BMl $\left[\mathrm{kg} / \mathrm{m}^{2}\right]$ & $24(19-29)$ & $25(20-29)$ & $23(19-27)$ \\
Total lgE $[\mathrm{kU} / \mathrm{L}]$ & $31(2-329)$ & $79(2-208)$ & $28(20-329)$ \\
sx1 $[n \geq 0.35 \mathrm{kUA} / \mathrm{L}]$ & 7 & 4 & 3 \\
\hline
\end{tabular}

Medians, minimum and maximum values are listed. $\mathrm{BMI}=$ body mass index. $\mathrm{Sx} 1$ is an indicator of sensitization to environmental allergens

\section{Blood parameters}

Markers of inflammation (blood cell counts, CRP, SAA, Club cell protein (CC16), IL-6) and coagulation (prothrombin F 1.2, endothelial microparticles, fibrinogen, D-dimers) were analyzed. The total and differential blood cell counts were determined using standard procedures with UniCell DxH800 (Beckman Coulter Inc., Brea CA, USA). Sandwich ELISA were used to measure CC16 (BioVendor, Brno, Czech Republic, range 1.57-50 ng/mL), IL-6 ( $\mathrm{R} \& \mathrm{D}$ Systems, Wiesbaden, Germany, range 4.7-600 pg/mL), SAA (Invitrogen $^{\text {тм }}$ Novex $^{\text {тм }}$ SAA Human ELISA Kit which detect serum amyloid A1 cluster, Carlsbad CA, USA, range 9.4-600 $\mathrm{ng} / \mathrm{mL}$ ), and CRP (high sensitive ELISA from Siemens Healthcare Diagnostics Products $\mathrm{GmbH}$, Marburg, Germany, precision levels down to or below $0.3 \mathrm{mg} / \mathrm{L}$ ) in serum.

The clotting factors were measured in plasma according to the manufacturer's instructions: Prothrombin cleavage fragment F1.2 with Enzygnost F1.2 (Siemens, range 69-229 pmol/L), endothelial microparticles with ZYMUPHEN MP (Hyphen Biomed, Neuville-sur-Oise, France, precision levels down to or below $5 \mathrm{nM}$ ), fibrinogen with a modified method from Clauss with Multifibren $U$ (Siemens, range 180-350 mg/dL), and D-dimers with Behring Coagulation System XP (BCS XP) and INNOVANCE DDimer (Siemens, precision levels down to or below $0.5 \mathrm{mg} / \mathrm{L})$.

\section{Biomonitoring}

Biomonitoring was performed by determination of zinc levels in blood and urine. Plastic materials were used for sample preparation to prevent contamination. Prior to usage, the vessels were cleaned with $1 \%$ nitric acid for $2 \mathrm{~h}$, rinsed with ultrapure water and dried at room temperature. After thawing the frozen aliquots, $50 \mu \mathrm{L}$ of the blood samples were diluted 1:100, and $500 \mu \mathrm{L}$ of the urine samples were diluted $1: 10$ with $0.1 \mathrm{M} \mathrm{HCl}$ solution and $100 \mu \mathrm{L}$ of a $0.2 \%$ solution of Triton-X. Rhodium was used as internal standard. Analysis was carried out using a 7700 ICP-MS system from Agilent Technologies in He-mode (flow rate $5 \mathrm{~mL} / \mathrm{min}$ ) with a collision cell to avoid interferences. Skimmer and sampler cones were made of nickel. Calibration and calculation of the $\mathrm{Zn}$ concentrations were carried out using standards at eight different concentrations. LOQ was $4.0 \mu \mathrm{g} / \mathrm{L}$. Materials from RECIPE (ClinChek Whole Blood Level, lyophil. For Trace Elements I and II, REF 8840, LOT 227; ClinChek Urine Control lyophil. For Trace Elements I and II, REF 8847-8849, LOT 122) and SERONORM (Trace Elements Whole Blood Level I and II, LOT 1103129, Trace Elements Urine Level I and II, LOT 1011644) served as internal control.

\section{FeNO}

Fractional exhaled nitric oxide was measured using a portable electrochemical analyzer (NIOX Mino, Aerocrine, Solna, Sweden) taking into account the guidelines of the American Thoracic Society and European Respiratory Society [16].

\section{Lung function testing}

Lung function was recorded using both body plethysmography [17] and spirometry [18] in a linked maneuver with a MasterLab (Jaeger, Würzburg, Germany). A battery of different parameters was evaluated (e.g. airway resistance, lung volumes, and flows).

\section{Data analysis}

Descriptive analysis was performed for each variable stratified by exposure (sham, 0.5, 1.0 and $2.0 \mathrm{mg} / \mathrm{m}^{3} \mathrm{ZnO}$ ) and time of measurement (before, during, immediately

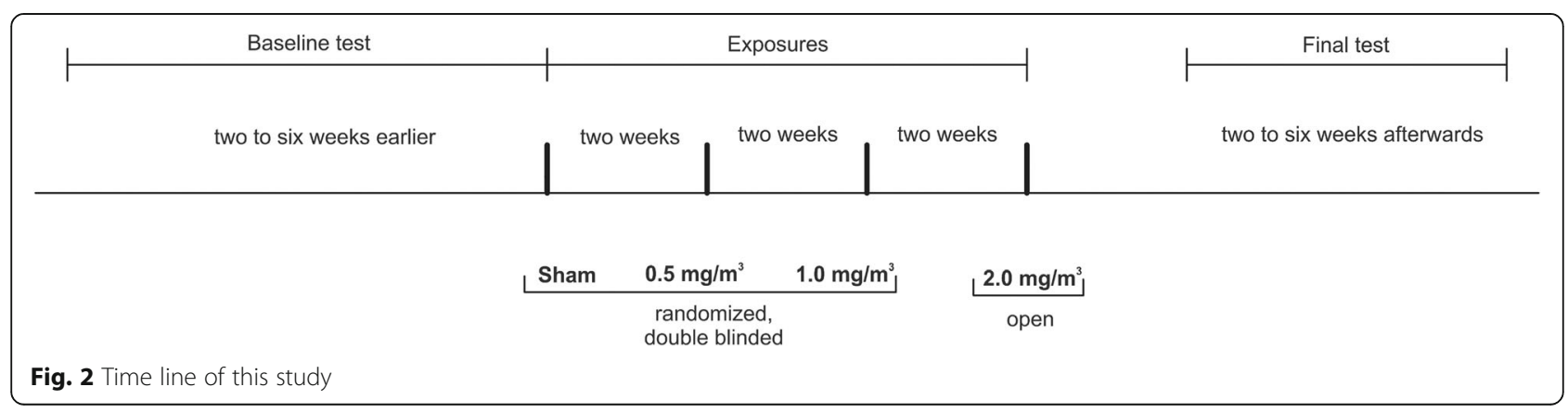


after, and $24 \mathrm{~h}$ post exposure). Characteristics of subjects were expressed as medians, 25\%- and 75\%-quantiles, as well as minimum and maximum. Graphical representations were illustrated with boxplots. Effects were compared between the before, immediately after, and $24 \mathrm{~h}$ after exposure. In addition, the effects after sham were compared to exposure after $\mathrm{ZnO}$. Exposure groups were compared using paired Student's t-test for normal or lognormal distributed variables. The problem of multiple comparisons was counteracted using the Bonferroni correction, by dividing the overall desired statistical significance level $\alpha=0.05$ by the number of hypotheses tested. Individual descriptive analyses were performed for body temperature with a cut-off of $\geq 37.5^{\circ} \mathrm{C}$. Spearman correlation coefficients $\left(\mathrm{r}_{\mathrm{S}}\right)$ were calculated to predict the monotone association between parameters.

Rank order tables were developed to give another estimate of increased effects which follow a concentrationresponse relationship. Increased effects were defined as values bigger than the largest value of baseline test, examinations before each exposure and final test $(n=6)$ plus the double median absolute deviation (MAD) of these 6 values (> max (baseline test, final test, initial investigation before start of exposure) $+2 \mathrm{MAD}$ ). Each of the $\mathrm{ZnO}$ related effects was assigned to ranks 1 to 4 , the lowest value represented by rank 1 and the highest by rank 4, respectively. All parameters were evaluated with both group comparisons and rank order tables.

\section{Results}

The results obtained from baseline tests, examinations done before each exposure, and from final tests $(n=6)$ were not significantly different from one another. In addition, when the final tests were conducted at the end of the study (minimum 14 days after the last exposure), all parameters had returned to levels that were within the range of the initial values. Consequently, only those parameters with significant changes are presented below. $\mathrm{ZnO}$ exposure had no effect on CC16, IL-6, clotting factors (prothrombin F 1.2, endothelial microparticles, fibrinogen, D-dimers) in blood, FeNO, and all lung function parameters.

\section{Questionnaire}

There was a small increase in the number of subjects with flu-like symptoms $24 \mathrm{~h}$ after exposure to $2.0 \mathrm{mg} / \mathrm{m}^{3}$ $\mathrm{ZnO}$ when compared to the number of complaints directly after exposure (Fig. 3). The same results were also obtained if the grading of severity of symptoms was considered (data not shown). Also there were no concentration-related effects with any other questions (data not shown).

\section{Body temperature}

With the exception of one male subject who suffered from an abdominal infection during the sham exposure, there was no significant increase in body temperature $\left(\geq 37.5^{\circ} \mathrm{C}\right)$ in subjects exposed to either sham or $0.5 \mathrm{mg} / \mathrm{m}^{3} \mathrm{ZnO}$. Only two subjects exposed to $1.0 \mathrm{mg} / \mathrm{m}^{3} \mathrm{ZnO}$ reported increased temperatures of $\geq 37.5{ }^{\circ} \mathrm{C}$; whereas, six subjects had elevated temperatures upon exposure to $2.0 \mathrm{mg} / \mathrm{m}^{3} \mathrm{ZnO}$. Furthermore, only one subject reported increased body temperature after exposure to both 1.0 and $2.0 \mathrm{mg} / \mathrm{m}^{3} \mathrm{ZnO}$. All temperature increases occurred between 8 to $10 \mathrm{~h}$ post exposure, with the maximum reported temperature of $39.5{ }^{\circ} \mathrm{C}$ in females and $38.6{ }^{\circ} \mathrm{C}$ in males. Importantly, the increase in temperature in all subjects was not significantly different within group comparisons.

\section{Blood parameters}

The concentration of the acute phase proteins CRP and SAA were highly correlated $\left(\mathrm{r}_{\mathrm{S}}=0.78\right)$ as illustrated in Fig. 4. The Spearman correlation coefficient of $r_{S}=0.78$ was calculated including all values at all exposure conditions. Coefficients for each concentration yielded similar results $\left(0 \mathrm{mg} / \mathrm{m}^{3} \mathrm{ZnO}: \mathrm{r}_{\mathrm{S}}=0.68,0.5 \mathrm{mg} / \mathrm{m}^{3}\right.$

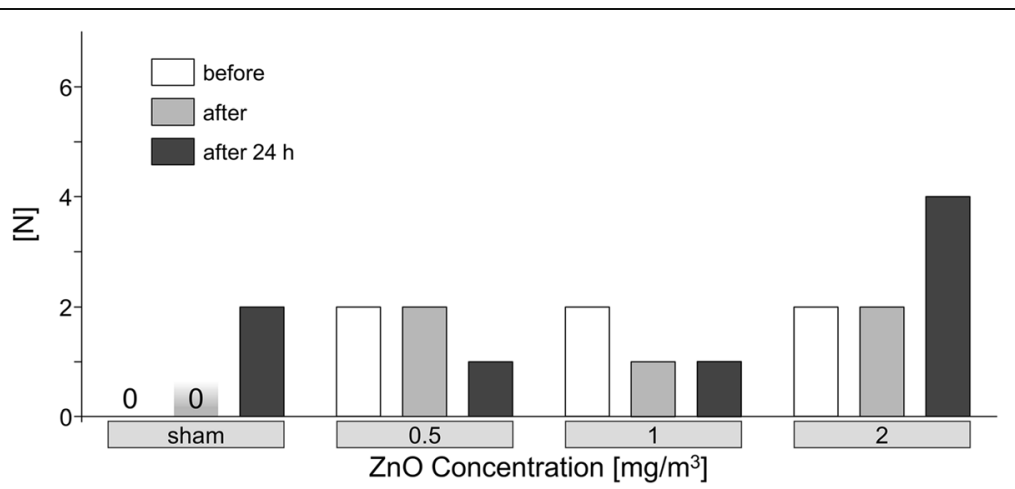

Fig. 3 Number of subjects with flu-like symptoms (at least 1 of 3 symptoms: feeling of fever, feeling sick and muscle pain) according to ZnO concentrations and time points 


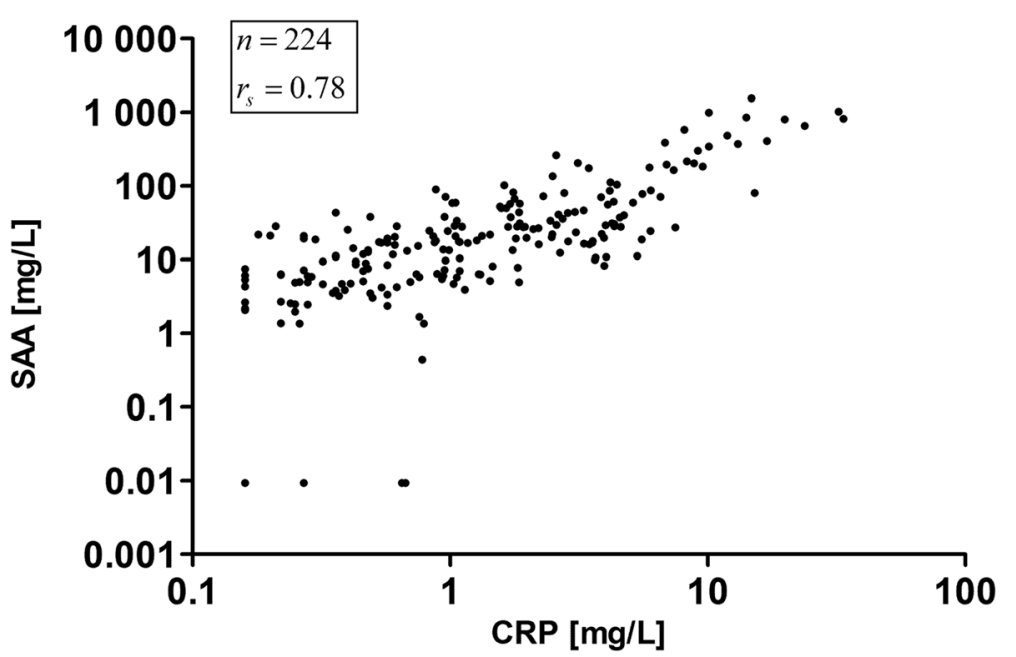

Fig. 4 Correlation plot of SAA vs. CRP. All values $(n=224)$ at all $\mathrm{ZnO}$ concentrations are shown

$\mathrm{ZnO}: \mathrm{r}_{\mathrm{S}}=0.86,1.0 \mathrm{mg} / \mathrm{m}^{3} \mathrm{ZnO}: \mathrm{r}_{\mathrm{S}}=0.74$ and $2.0 \mathrm{mg} /$ $\left.\mathrm{m}^{3} \mathrm{ZnO}: \mathrm{r}_{\mathrm{S}}=0.89\right)$.

Exposure to $\mathrm{ZnO}$ led to a concentration-dependent increase in both CRP and SAA levels in the blood $24 \mathrm{~h}$ after exposure. When compared to the levels before exposure, blood CRP levels significantly increased with all $\mathrm{ZnO}$ concentrations $24 \mathrm{~h}$ after exposure. Conversely, SAA levels increased $24 \mathrm{~h}$ after exposure to 1.0 and $2.0 \mathrm{mg} / \mathrm{m}^{3} \mathrm{ZnO}$ (Fig. 5). Compared to the sham exposure, $\mathrm{ZnO}$ exposures yielded significantly higher CRP values $24 \mathrm{~h}$ after exposure to $2.0 \mathrm{mg} / \mathrm{m}^{3}$ $\mathrm{ZnO}$, and higher SAA values after 1.0 and $2.0 \mathrm{mg} / \mathrm{m}^{3}$ $\mathrm{ZnO}$ (Fig. 5).

Absolute and relative numbers of neutrophil granulocytes were similar to each other and as a result only the relative numbers were shown as a percentage (Fig. 5c) (absolute numbers not shown). In contrast to the acute phase proteins, neutrophil levels increased significantly immediately after all exposure scenarios (including sham), but not in a concentration-dependent relationship, suggesting an effect of the physical exercise [19]. A concentration-response was observed only after $24 \mathrm{~h}$ after exposure. Neutrophil levels increased $24 \mathrm{~h}$ after exposure to 1.0 and $2.0 \mathrm{mg} / \mathrm{m}^{3} \mathrm{ZnO}$ compared to levels before the exposure (Fig. 5). Furthermore, compared to the sham exposure, all concentrations of $\mathrm{ZnO}$ elicited significant increases in neutrophils 24 h later (Fig. 5).

Four subjects showed increased CRP levels upon exposure to sham exposures as illustrated in the rank order tables, including the one subject (ID 3) with an acute abdominal infection (Table 3 ). The effect increased with increasing $\mathrm{ZnO}$ concentrations with 6 subjects (CRP) after $0.5 \mathrm{mg} / \mathrm{m}^{3} \mathrm{ZnO}, 12$ subjects (CRP and SAA) after $1.0 \mathrm{mg} / \mathrm{m}^{3} \mathrm{ZnO}$, and up to 15 subjects (CRP) after $2.0 \mathrm{mg} / \mathrm{m}^{3} \mathrm{ZnO}$. The acute phase proteins
(CRP and SAA) increased in a concentration dependent manner after exposures to 1.0 and $2.0 \mathrm{mg} / \mathrm{m}^{3} \mathrm{ZnO}$. In contrast, neutrophils and body temperature significantly increased only after $2.0 \mathrm{mg} / \mathrm{m}^{3} \mathrm{ZnO}$. No susceptible subjects were identified, because increased effects occurred in all subjects, without increased frequency in single subjects (Table 3 ).

There were no differences between males and females, as well as between subjects with and without sensitizations to environmental allergens (data not shown). Levels of $\mathrm{Zn}$ in blood and urine were unaffected by $\mathrm{ZnO}$ inhalation at any concentration (data not shown). This is due to the naturally occurring high zinc concentrations in the blood, which are in the range between 4 to $7.5 \mathrm{mg} / \mathrm{L}$ whole blood [20]. In addition, the concentration shows large fluctuations, influenced by food intake, but the diet of our subjects was not standardized in this study.

\section{Calculation of deposition rates of inhaled $\mathrm{ZnO}$ particles}

We used the ICRP model [21] to identify possible differences of deposition rates of $\mathrm{ZnO}$ particles with different median diameters in the tracheobronchial and alveolar region. Due to the way of particle generation, the median diameter of the $\mathrm{ZnO}$ particles at $0.5 \mathrm{mg} / \mathrm{m}^{3}$ with $47.8 \mathrm{~nm}$ increases at $1.0 \mathrm{mg} / \mathrm{m}^{3} \mathrm{ZnO}$ to $62.8 \mathrm{~nm}$ and at $2.0 \mathrm{mg} / \mathrm{m}^{3} \mathrm{ZnO}$ to $85.8 \mathrm{~nm}$. The estimations of the deposition rates were performed under the following conditions: The $\mathrm{ZnO}$ particles are ideal spheres, the measured mobility diameter corresponds to the activity median aerodynamic diameter in the ICRP model and the density of the particles is $1 \mathrm{~g} / \mathrm{cm}^{3}$. We used the data of the "Reference Worker" in this model. Table 4 shows the estimation of deposition rates in dependence of different particle size and lung compartments. 

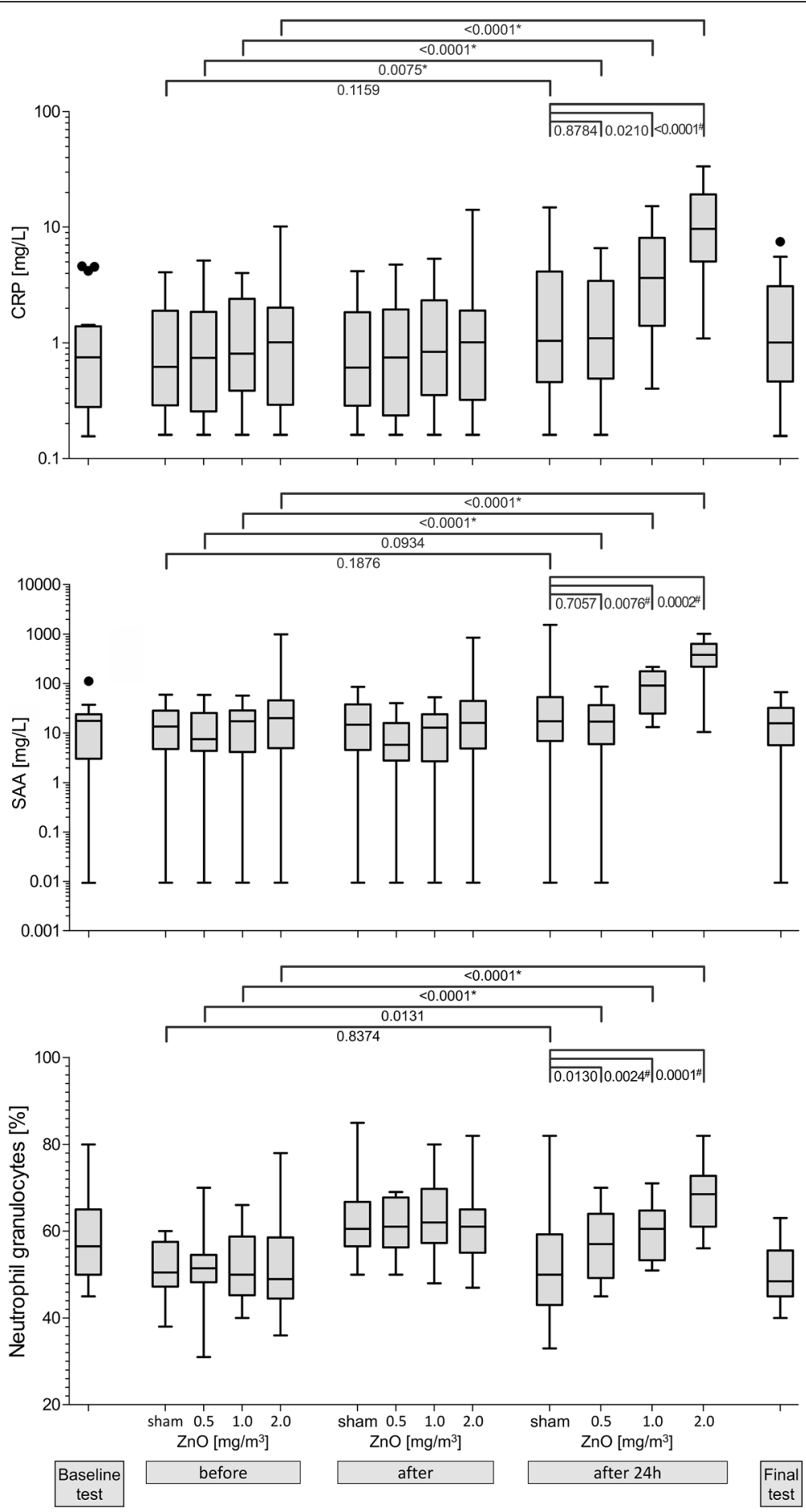

Fig. 5 Selected blood parameters according to $\mathrm{ZnO}$ concentrations and time points. ${ }^{*}$ significant values with significance level $a=0.0125$ (after Bonferroni correction). " significant values with significance level $a=0.0167$ (after Bonferroni correction). Outliers are defined as values above median $+1.5 \mathrm{x}$ interquartile range or values below median $-1.5 \mathrm{x}$ interquartile range

\section{Discussion}

Experimental inhalation studies in humans with nanoparticles, which use multiple concentration steps in order to describe a concentration-response relationship are extremely sparse. The present study is, to our knowledge, the first human inhalation study with pure nanosized $\mathrm{ZnO}$ in the concentration range of 0.5 to $2.0 \mathrm{mg} /$ $\mathrm{m}^{3}$. A key result of this study is the demonstration of 
Table 3 Rank order tables

\begin{tabular}{|c|c|c|c|c|c|c|c|c|c|c|c|c|c|c|c|c|}
\hline \multirow[t]{2}{*}{ ID } & \multicolumn{4}{|c|}{$\begin{array}{c}\text { Temperature } \\
\text { ZnO-Conc. [mg/m³] }\end{array}$} & \multicolumn{4}{|c|}{$\begin{array}{c}\text { CRP } \\
\text { ZnO-Conc. }\left[\mathrm{mg} / \mathrm{m}^{3}\right]\end{array}$} & \multicolumn{4}{|c|}{$\begin{array}{c}\text { SAA } \\
\text { ZnO-Conc. }\left[\mathrm{mg} / \mathrm{m}^{3}\right]\end{array}$} & \multicolumn{4}{|c|}{$\begin{array}{c}\text { Neutrophils [\%] } \\
\text { ZnO-Conc. }\left[\mathrm{mg} / \mathrm{m}^{3}\right]\end{array}$} \\
\hline & 0 & 0.5 & 1.0 & 2.0 & 0 & 0.5 & 1.0 & 2.0 & 0 & 0.5 & 1.0 & 2.0 & 0 & 0.5 & 1.0 & 2.0 \\
\hline 1 & 3 & 1 & 2 & 4 & 1 & 2 & 3 & 4 & 1 & 2 & 3 & 4 & 1 & 2 & 3 & 4 \\
\hline 2 & 1 & 2 & 3 & 4 & 1 & 2 & 3 & 4 & 1 & 2 & 3 & 4 & 2 & 1 & 3 & 4 \\
\hline 3 & 4 & 1 & 2 & 3 & 4 & 1 & 2 & 3 & 4 & 1 & 2 & 3 & 4 & 3 & 1 & 2 \\
\hline 4 & 1 & 4 & 3 & 2 & 2 & 1 & 3 & 4 & 2 & 1 & 3 & 4 & 4 & 1 & 2 & 3 \\
\hline 5 & 1 & 2 & 4 & 3 & 1 & 2 & 3 & 4 & 2 & 1 & 3 & 4 & 1 & 2 & 3 & 4 \\
\hline 6 & 1 & 3 & 2 & 4 & 1 & 1 & 3 & 4 & 2 & 1 & 3 & 4 & 1 & 3 & 2 & 4 \\
\hline 7 & 1 & 2 & 3 & 4 & 1 & 2 & 3 & 4 & 2 & 1 & 3 & 4 & 1 & 2 & 3 & 4 \\
\hline 8 & 3 & 4 & 1 & 1 & 1 & 2 & 3 & 4 & 4 & 1 & 2 & 3 & 1 & 2 & 3 & 4 \\
\hline 9 & 3 & 1 & 4 & 2 & 1 & 2 & 3 & 4 & 1 & 2 & 3 & 4 & 1 & 4 & 2 & 3 \\
\hline 10 & 1 & 1 & 3 & 4 & 2 & 1 & 3 & 4 & 2 & 1 & 3 & 4 & 1 & 1 & 3 & 4 \\
\hline 11 & 2 & 1 & 3 & 4 & 1 & 2 & 3 & 4 & 1 & 2 & 3 & 4 & 1 & 2 & 3 & 4 \\
\hline 12 & 4 & 1 & 2 & 3 & 1 & 2 & 3 & 4 & 2 & 1 & 3 & 4 & 1 & 2 & 2 & 4 \\
\hline 13 & 4 & 1 & 4 & 4 & 1 & 3 & 2 & 4 & 3 & 1 & 2 & 4 & 1 & 3 & 2 & 3 \\
\hline 14 & 1 & 3 & 1 & 4 & 1 & 2 & 3 & 4 & 1 & 2 & 3 & 4 & 1 & 2 & 3 & 4 \\
\hline 15 & 2 & 1 & 4 & 3 & 2 & 1 & 3 & 4 & 1 & 2 & 3 & 4 & 1 & 2 & 3 & 4 \\
\hline 16 & 2 & 1 & 3 & 4 & 2 & 1 & 3 & 4 & 1 & 2 & 3 & 4 & 1 & 4 & 3 & 2 \\
\hline
\end{tabular}

Grey colored cells represent increased effects defined as $>$ max value of baseline test, final test and initial investigation before start of exposure plus double median absolute deviation (MAD) of these 6 values. Numbers indicate ranks of effects

such a concentration-response relationship. The most sensitive outcomes were the increase in acute phase proteins (CRP and SAA) and neutrophils in blood, followed by an increase in body temperature and the occurrence of flu-like symptoms at and above $1 \mathrm{mg} / \mathrm{m}^{3} \mathrm{ZnO}$.

No relevant effects were detectable after sham exposures, but initial increases of acute phase proteins were observed with a concentration of $0.5 \mathrm{mg} / \mathrm{m}^{3} \mathrm{ZnO}$ after $24 \mathrm{~h}$. Pronounced effects on acute phase proteins and neutrophils occurred after $1.0 \mathrm{mg} / \mathrm{m}^{3} \mathrm{ZnO}$, together with increases in body temperature in some subjects. All the effects were strongest after $2.0 \mathrm{mg} / \mathrm{m}^{3} \mathrm{ZnO}$, with flu-like symptoms and elevated body temperature measured in several subjects.

The results of this study are in accordance with previous studies that reported effects (flu-like symptoms, increase in temperature and inflammatory markers) after exposure to $\geq 2.5 \mathrm{mg} / \mathrm{m}^{3} \mathrm{ZnO}$ [2-4]. The only previous study that investigated lower concentrations, i.e. $0.5 \mathrm{mg} /$ $\mathrm{m}^{3} \mathrm{ZnO}$ [5] showed no effects, but importantly, the duration of exposure was only $2 \mathrm{~h}$ without physical exercise, resulting in an approximately 4 fold lower inhaled dose (with linear extrapolation) of $\mathrm{ZnO}$ in comparison with our lowest $\mathrm{ZnO}$ dose. The findings of the present study are also compatible with a previous study investigating $\mathrm{ZnO}$-containing welding fumes [8], which showed an increase in CRP levels after $6 \mathrm{~h}$ exposure to $1.5 \mathrm{mg} / \mathrm{m}^{3}$ zinc with short periods of physical exercise.

Our investigations were conducted with $\mathrm{ZnO}$ as a single component in the nanoscale range at maximal concentrations considered to represent high workplace exposures [12]. The observed effects in this study were caused only by the different airborne $\mathrm{ZnO}$ concentrations. Any influences from secondary components of welding fume and trace gases are negligible. Possible effect differences due to different deposition rates of $\mathrm{ZnO}$ particles with concentration-dependent median diameters (see Table 1) can be nearly excluded. Our estimation with the help of the ICRP model revealed similar deposition rates of the different particle sizes in this study in terms of both total deposition (sum of alveolar, inhalable and tracheobronchial) and alveolar deposition alone (see Table 4).

The effects measured in this study are indicative of systemic inflammation which may be explained by either primary local inflammation of the respiratory tract/lung and secondary resorption of inflammatory markers, or by primary systemic inflammation due to resorbed zinc ions. The latter mechanism is supported by the 4.8 to $19.2 \mathrm{~h}$ half-life

Table 4 Estimated depostion rates of $\mathrm{ZnO}$ in the current study

\begin{tabular}{llll}
\hline $\begin{array}{l}\text { Particle concentration } \\
{\left[\mathrm{mg} / \mathrm{m}^{3}\right]}\end{array}$ & $\begin{array}{l}\text { Median particle diameter } \\
{[\mathrm{nm}]}\end{array}$ & $\begin{array}{l}\text { ZnO deposition rate } \\
\text { (sum of tracheobronchial, } \\
\text { inhalable and alveolar) }\end{array}$ & $\begin{array}{l}\text { ZnO deposition rate } \\
\text { (alveolar) }\end{array}$ \\
\hline 0.5 & 47.8 & $78 \%$ & $48 \%$ \\
1.0 & 62.8 & $74 \%$ & $47 \%$ \\
2.0 & 85.8 & $66 \%$ & $44 \%$ \\
\hline
\end{tabular}


of $\mathrm{ZnO}$ particles in rat lungs [22, 23]. In addition, Cho et al. [24] hypothesized that the rapid $\mathrm{pH}$-dependent dissolution of $\mathrm{ZnO}$ particles inside phagosomes is the main cause of $\mathrm{ZnO}$-induced diverse progressive lung injuries. It has been shown in an ex-vivo study that the release of $\mathrm{Zn}$ ions from $\mathrm{ZnO}$ nanoparticles, due to their instability in the acidic compartment of lysosomes, increases reactive oxygen species generation and damage of lysosomal membranes and activation of executioner caspase-3 and caspase-7 [25]. The $\mathrm{ZnO}$-induced effects strongly argue for a zinc-specific mechanism, since the distinct clinical presentations of metal fume fever by $\mathrm{ZnO}$ as well as other metal compounds, have not been observed after exposure to poorly soluble particles (PSP) [26].

While the acute phase proteins in blood clearly increased after $\mathrm{ZnO}$ inhalation, effects on further inflammatory parameter in the blood, such as IL-6 and the secreted CC16 as of a marker of increased lung permeability could not be detected and thus a complete inflammatory response could not be observed in the blood samples obtained at the selected time points. Very recently, it was shown that IL-6 increased $10 \mathrm{~h}$ after the start of a $6 \mathrm{~h}$ exposure to zinc-containing welding fumes, but this increase was not seen $29 \mathrm{~h}$ after the start of exposure [10]. Thus, it is probable that an increase in IL-6 concentration in the blood was overlooked due to the time intervals of the blood sampling in the present study. The increase in body temperature in a subset of subjects suggests susceptibility. Interestingly, increases in inflammatory markers were observed in all subjects a finding that does not support the concept that only susceptible individuals are affected.

Generally, chronic effects cannot be derived from acute human inhalation experiments. The observation that zinc fever occurs predominantly on the first day after periods without exposure to zinc-containing fumes suggests poorly understood adaptation processes. Zinc fever is proposed to be an acute disease, but epidemiologic information on the long-term consequences of exposure is limited. Our data clearly demonstrate that all observed effects were reversible at the time of the final tests.

Inflammatory systemic biomarkers have been proposed as biomarkers of cancer [27, 28], heart diseases [29-31] and chronic obstructive pulmonary disease and comorbidities [32] in epidemiological studies. However, it is unknown whether the association between inflammatory markers and disease is causal. A number of controlled studies in humans report increased levels of CRP or SAA after particle inhalation, and it is believed that this acute phase pulmonary and systemic response following particle inhalation may indeed constitute a causal link between particle inhalation and for example cardiovascular disease [33]. Very recently, it was shown for the first time that anti-inflammatory therapy led to a significantly lower rate of recurrent cardiovascular events than placebo [34]. This finding strengthens the view that inflammation is indeed causal, thus prevention of cardiovascular disease should comprise, among other measures, minimization of particle inhalation.

It has been reported earlier that pulmonary inflammatory responses following zinc oxide particle inhalation were much stronger than after inhalation of PSP like magnesium oxide. Thus particle composition is a major contributor to inflammation [26]. Epidemiological studies with cancer and cardiovascular disease as endpoints do not exist in predominantly $\mathrm{ZnO}$ exposed occupational cohorts. A dose-dependent association between welding fumes and lung cancer has been described for welders [35], and there are weak indications that welding fumes are a risk factor for cardiovascular diseases [36, 37]. The inflammatory acute response after $\mathrm{ZnO}$ inhalation in our study was reversible within a few weeks. It remains to be assessed whether repeated or chronic exposure to $\mathrm{ZnO}$ increase the risk for diseases which have been shown to be associated with environmental particle inhalation.

One weakness of the present study is that the effect parameters were recorded at limited time points, suggesting that some effects were overlooked due to their shorter or longer kinetics. However, the time points of the increases in the most sensitive parameters - CRP and SAA - in this study correspond well with other evaluations [10]. A further weakness is the lack of blinding of the highest $\mathrm{ZnO}$ concentration. In general, inhalation studies should be blinded, but for security reasons due the high $\mathrm{ZnO}$ concentrations, this was not performed. However, confounding of objective inflammatory markers in blood should be negligible.

For most of the effect parameters in this study, reference values do not exist or show large inter-individual variability. Thus, with the exception of body temperature (with well-known reference values), descriptive analyses with respect to reference values and interpretations of the magnitudes of the effects were not considered. In this study, two different group comparisons (before / after exposure; sham / $\mathrm{ZnO}$ ) and additional intra-individual analyses by rank order tables were used. The latter were developed in order to overcome the problem of multiple testing and associated definition of significant effects. Here six control scenarios were available, thus accidental variabilities were minimized. A strength of this study is the lack of effects after sham exposures, with the exception of one subject with an abdominal infection, as well as rare and minor unexplained increases of CRP (but not SAA) in three females. The lack of increased effects in sham exposures, 
and the consistent concentration-related effects in almost all subjects add to the credibility of the study results.

\section{Conclusions}

In summary, this study was able to demonstrate a concentration-response relationship of $\mathrm{ZnO}$ nanoparticles with clear systemic effects at and above $1 \mathrm{mg} / \mathrm{m}^{3}$ $\mathrm{ZnO}$. The results are in accordance with previous experimental studies that showed no effects at $0.5 \mathrm{mg} /$ $\mathrm{m}^{3} \mathrm{ZnO}$ [5] and clear effects concerning CRP with concentrations between 1.1 and $1.5 \mathrm{mg} / \mathrm{m}^{3} \mathrm{ZnO}$-containing welding fumes [9]. Similarly an increase of SAA was observed after inhalation of zinc or copper containing welding fumes [38], but the different exposure scenarios within these studies have to be considered. A No Effect Exposure Level (NOEL) derived from our study would be defined between 0.5 and $1 \mathrm{mg} / \mathrm{m}^{3}$, although, in contrast to a previous study with $2 \mathrm{~h}$ exposures at rest [5], initial effects were seen with $\mathrm{ZnO}$ exposures of $0.5 \mathrm{mg}$ / $\mathrm{m}^{3}$ concerning CRP and SAA, which were the most sensitive parameters. Exposure limits of $\mathrm{ZnO}$ in many countries (e.g. USA, United Kingdom, Australia, Canada) were set to $5.0 \mathrm{mg} / \mathrm{m}^{3}$ [39]. As this and more recent experimental studies showed effects far below this concentration, it is highly recommended to reassess the exposure limit for $\mathrm{ZnO}$ at workplaces.

\section{Abbreviations}

BMI: Body mass index; CC16: Club cell protein; CRP: C-reactive protein; FeNO: fractional exhaled nitric monoxide; GSD: geometric standard deviation; IL-6: interleukin-6; MAD: median absolute deviation; MIG: metal inert gas welding; NO: nitrogen monoxide; $\mathrm{NO}_{2}$ : nitrogen dioxide; NOEL: No observed effect level; PM $_{10}$ : Particulate matter with an aerodynamic diameter smaller than $10 \mu \mathrm{m}$; PSP: Poorly soluble particles; $r_{s}$ : Spearman correlation coefficients; SAA: Serum amyloid A; SMPS: Scanning mobility particle sizer; TEOM: Tapered elemental oscillating microbalance; ZnO: Zinc oxide

\section{Acknowledgments}

We are grateful to our volunteers for their participation. The authors thank Sabine Bernard, Gerda Borowitzki, Anja Deckert, Jennifer Gili, Evelyn Heinze, Claudia Litzenberger, Ursula Meurer, Melanie Ulbrich and Susann Widmer for their excellent technical assistance. We acknowledge the valuable contribution to the discussion of the results of this study of Martin Wieske (German Association of non-ferrous Metals), Heiko Udo Käfferlein, Dirk Pallapies, Dirk Taeger and Gerhard Schlüter (IPA).

\section{Funding}

This work was supported by the German Association of non-ferrous Metals.

\section{Availability of data and materials}

The datasets used and/or analyzed during the current study are available from the corresponding author on reasonable request.

\section{Authors' contributions}

Conception and design: $\mathrm{CM}, \mathrm{OH}, \mathrm{MR}, \mathrm{JB}, \mathrm{TB}, \mathrm{RM}$. Analysis and interpretation: $\mathrm{BJ}, \mathrm{VK}, \mathrm{BK}, \mathrm{VG}, \mathrm{GK}, \mathrm{EM}, \mathrm{CM}, \mathrm{OH}, \mathrm{RM}$. Biomonitoring: TW, NU. Drafting the manuscript for important intellectual content: $\mathrm{CM}, \mathrm{OH}, \mathrm{RM}$. All authors read and approved the final manuscript.

\section{Ethics approval and consent to participate}

The study was approved by the ethics committee of the RuhrUniversity Bochum (No. 4929-14). All experimental work was conducted in accordance with the Declaration of Helsinki. Subjects gave written informed consent to participate.

Consent for publication

Not applicable.

Competing interests

The authors declare that they have no competing interests.

\section{Publisher's Note}

Springer Nature remains neutral with regard to jurisdictional claims in published maps and institutional affiliations.

\section{Author details}

${ }^{1}$ Institute for Prevention and Occupational Medicine of the German Social Accident Insurance, Institute of the Ruhr-Universität Bochum (IPA),

Bürkle-de-la-Camp-Platz 1, 44789 Bochum, Germany. ${ }^{2}$ Gerinnungszentrum Rhein-Ruhr, Königstraße 13, 47051 Duisburg, Germany.

Received: 13 October 2017 Accepted: 22 January 2018

Published online: 12 February 2018

\section{References}

1. Nemery B. Metal toxicity and the respiratory tract. Eur Respir J. 1990;3:202-19.

2. Gordon T, Chen LC, Fine JM, Schlesinger RB, Su WY, Kimmel TA, Amdur M. Pulmonary effects of inhaled zinc oxide in human subjects, guinea pigs, rats, and rabbits. Am Ind Hyg Assoc J. 1992;53:503-9.

3. Fine J, Gordon T, Chen LC, Kinney P, Falcone G, Beckett W. Metal fume fever: Caracterization of clinical and plasma IL-6 responses in controlled human exposures to zinc oxide fume at and below the threshold limit value. J Occup Environ Med. 1997;39:722-6.

4. Kuschner WG, D'Alessandro A, Wintermeyer SF, Wong H, Boushey HA, Blanc PD. Pulmonary responses to purified zinc oxide fume. J Investig Med. 1995:43:371-8.

5. Beckett WS, Chalupa DF, Puly-Brown A, Speers DM, Stewart JC, Frampton MW, Utell MJ, Huang LS, Cox C, Zareba W, Oberdörster G. Comparing inhaled ultrafine versus fine zinc oxide particles in healthy humans. Am J Respir Crit Care Med. 2005;171:1129-35.

6. Blanc $\mathrm{P}$, Wong $\mathrm{H}$, Bernstein MS, Boushey HA. An experimental human model of metal fume fever. Ann Int Med. 1991;114:930-6.

7. Blanc PD, Boushey HA, Wong H, Wintermeyer SF, Bernstein MS. Cytokines in metal fume fever. Am Rev Respir Dis. 1993;147:134-8.

8. Hartmann L, Bauer M, Bertram J, Gube M, Lenz K, Reisgen U, Schettgen T, Kraus T, Brand P. Assessment of the biological effects of welding fumes emitted from metal inert gas welding processes of aluminium and zincplated materials in humans. Int J Hyg Environ Health. 2014;217:160-8.

9. Brand P, Bauer M, Gube M, Lenz K, Reisgen U, Spiegel-Ciobanu VE, Kraus T. Relationship between welding fume concentration and systemic inflammation after controlled exposure of human subjects with welding fumes from metal inert gas brazing of zinc-coated materials. J Occup Environ Med. 2014;56:1-5.

10. Baumann R, Joraslafsky S, Markert A, Rack I, Davatgarbenam S, Kossack V, Gerhards B, Kraus T, Brand P, Gube M. IL-6, a central acute-phase mediator, as an early biomarker for exposure to zinc-based metal fumes. Toxicology. 2016;373:63-73.

11. Monsé C, Monz C, Dahmann D, Asbach C, Stahlmecke B, Lichtenstein N, Buchwald K-E, Merget R, Bünger J, Brüning T. Development and evaluation of a nanoparticle generator for human inhalation studies with airborne zinc oxide. Aerosol Sci Technol. 2014:48:418-26.

12. Reisgen U, Olschok S, Lenz K, Spiegel-Ciobanu VE. Ermittlung von Schweißrauchdaten und Partikelkenngrößen bei verzinkten Werkstoffen. Schweissen und Schneiden. 2012;64:788-96.

13. Pillar F, Kahl A, Brüning T, Monsé $C$. Validierungsuntersuchungen eines Berechnungsmodells zur Ausbreitung von Gefahrstoffen. Gefahrst Reinhalt L. 2016;76:19-25.

14. Merget R, Heinze E, Neumann L, Taeger D, Bruening T. Comparison of the Pari Provotest II reservoir- and the ATS dosimeter method for the assessment of bronchial hyperresponsiveness. In: Bruening T, Harth $\mathrm{V}$, Zaghow M, editors. Proceedings of the 45th annual meeting of the German Society for Occupational and Environmental Medicine. Stuttgart: Gentner Publishing Company; 2005. p. 624-5. 
15. Monsé C, Sucker K, van Thriel C, Broding HC, Jettkant B, Berresheim H, Wiethege $T$, Käfferlein $H$, Merget R, Bünger J, Brüning T. Considerations for the design and technical setup of a human whole-body exposure chamber. Inhal Toxicol. 2012;24:99-108.

16. American Thoracic Society and European Respiratory Society (ATS/ERS). Recommendations for standardized procedures for the online and offline measurement of exhaled lower respiratory nitric oxide and nasal nitric oxide, 2005. Am J Respir Crit Care Med. 2005;171:912-30.

17. Criée CP, Sorichter S, Smith HJ, Kardos P, Merget R, Heise D, Berdel D, Köhler D, Magnussen H, Marek W, Mitfessel H, Rasche K, Rolke M, Worth H, Jörres RA. Bodyplethysmography - its principles and clinical use. Respir Med. 2011;105:959-73.

18. American Thoracic Society. Standardization of spirometry, 1994 update. Am J Respir Crit Care Med. 1995;152:1107-36.

19. Szlezak AM, Szlezak SL, Keane J, Tajouri L, Minahan C. Establishing a doseresponse relationship between acute resistance-exercise and the immune system: protocol for a systematic review. Immunol Lett. 2016;180:54-65.

20. Thomas L. Labor und Diagnose: Indikation und Bewertung von Laborbefunden für die medizinische Diagnostik. 2007. ISBN-10: 3980521567 ISBN-13: 978-3980521567.

21. International Commission for Radiological Protection (ICRP). Human respiratory tract model for radiological protection. ICRP publication 66 Ann ICRP. 1994;24:1-3.

22. Hollinger MA, Raabe OG, Giri SN, Freywald M, Teague SV, Tarkington B. Effect of the inhalation of zinc and dietary zinc on paraquat toxicity in the rat. Toxicol Appl Pharmacol. 1979;49:53-61.

23. Pauluhn J. Derivation of occupational exposure levels (OELs) of low-toxicity isometric biopersistent particles: how can the kinetic lung overload paradigm be used for improved inhalation toxicity study design and OELderivation? Part Fibre Toxicol. 2014;11:72.

24. Cho WS, Duffin R, Howie SE, Scotton CJ, Wallace WA, Macnee W, Bradley M, Megson IL, Donaldson K. Progressive severe lung injury by zinc oxide nanoparticles; the role of $\mathrm{Zn} 2+$ dissolution inside lysosomes. Part Fibre Toxicol. 2011:8:27.

25. Syama S, Sreekanth PJ, Varma HK, Mohanan PV. Zinc oxide nanoparticles induced oxidative stress in mouse bone marrow mesenchymal stem cells. Toxicol Mech Methods. 2014;24:644-53.

26. Kuschner WG, Wong H, Dalessandro A, Quinlan P, Blanc PD. Human pulmonary responses to experimental inhalation of high concentration fine and ultrafine magnesium oxide particles. Environ Health Perspect. 1997;105:1234-7.

27. Allin KH, Bojesen SE, Nordestgaard BG. Baseline C-reactive protein is associated with incident cancer and survival in patients with cancer. J Clin Oncol. 2009;27:2217-24.

28. Allin $\mathrm{KH}$, Nordestgaard BG. Elevated C-reactive protein in the diagnosis, prognosis, and cause of cancer. Crit Rev Clin Lab Sci. 2011; 48:155-70.

29. Rietzschel E, De Buyzere M. High-sensitive C-reactive protein: universal prognostic and causative biomarker in heart disease? Biomark Med. 2012;6:19-34.

30. Kounis NG, Soufras GD, Tsigkas G, Hahalis G. White blood cell counts, leukocyte ratios, and eosinophils as inflammatory markers in patients with coronary artery disease. Clin Appl Thromb Hemost. 2015;21:139-43.

31. Getz GS, Krishack PA, Reardon CA. Serum amyloid a and atherosclerosis. Curr Opin Lipidol. 2016;27:531-5.

32. Thomsen $M$, Dahl M, Lange $P$, Vestbo J, Nordestgaard BG. Inflammatory biomarkers and comorbidities in chronic obstructive pulmonary disease. Am J Respir Crit Care Med. 2012;186:982-8.

33. Saber AT, Jacobsen NR, Jackson P, Poulsen SS, Kyjovska ZO, Halappanavar S, Yauk $\mathrm{CL}$, Wallin $\mathrm{H}$, Vogel U. Particle-induced pulmonary acute phase response may be the causal link between particle inhalation and cardiovascular disease. Wiley Interdiscip Rev Nanomed Nanobiotechnol. 2014;6:517-31.

34. Ridker PM, Everett BM, Thuren T, MacFadyen JG, Chang WH, Ballantyne C, Fonseca F, Nicolau J, Koenig W, Anker SD, JJP K, Cornel JH, Pais P, Pella D, Genest J, Cifkova R, Lorenzatti A, Forster T, Kobalava Z, Vida-Simiti L, Flather M, Shimokawa H, Ogawa H, Dellborg M, PRF R, RPT T, Libby P, Glynn RJ, CANTOS Trial Group. Antiinflammatory therapy with Canakinumab for atherosclerotic disease. N Engl J Med. 2017;377:1119-31.

35. : Kendzia B, Behrens T, Jöckel KH, Siemiatycki J, Kromhout H, Vermeulen R, Peters S, Van Gelder R, Olsson A, Brüske I, Wichmann HE, Stücker I, Guida F. Tardón A, Merletti F, Mirabelli D, Richiardi L, Pohlabeln H, Ahrens W, Landi
MT, Caporaso N, Consonni D, Zaridze D, Szeszenia-Dabrowska N, Lissowska J, Gustavsson P, Marcus M, Fabianova E, 't Mannetje A, Pearce N, Tse LA, Yu IT, Rudnai P, Bencko V, Janout V, Mates D, Foretova L, Forastiere F, McLaughlin J, Demers P, Bueno-de-Mesquita B, Boffetta P, Schüz J, Straif K, Pesch B, Brüning T. Welding and lung cancer in a pooled analysis of casecontrol studies. Am J Epidemiol 2013;178:1513-1525.

36. Li H, Hedmer M, Kåredal M, Björk J, Stockfelt L, Tinnerberg H, Albin M, Broberg K. A cross-sectional study of the cardiovascular effects of welding fumes. PLoS One. 2015;10:e0131648.

37. Ibfelt E, Bonde JP, Hansen J. Exposure to metal welding fume particles and risk for cardiovascular disease in Denmark: a prospective cohort study. Occup Environ Med. 2010;67:772-7

38. Baumann R, Gube M, Markert A, Davatgarbenam S, Kossack V, Gerhards B, Kraus T, Brand P. Systemic serum amyloid $A$ as a biomarker for exposure to zinc and/or copper-containing metal fumes. J Expo Sci Environ Epidemiol 2017 [Epub ahead of print]

39. GESTIS Substance Database. Information system on hazardous substances of the German Social Accident Insurance. 2017; http://limitvalue.ifa.dguv.de

\section{Submit your next manuscript to BioMed Central and we will help you at every step:}

- We accept pre-submission inquiries

- Our selector tool helps you to find the most relevant journal

- We provide round the clock customer support

- Convenient online submission

- Thorough peer review

- Inclusion in PubMed and all major indexing services

- Maximum visibility for your research

Submit your manuscript at www.biomedcentral.com/submit
) Biomed Central 